\title{
Non-autologous human bone graft applied to upper maxillary sinus elevation
}

\section{Injerto de hueso humano no autólogo aplicado a la elevación del seno maxilar superior}

\author{
Ricardo Bachur ${ }^{1}$, Carlos Bornancini ${ }^{1}$, María Eugenia Battisti ${ }^{1}$, Juan Cima $^{1}$, Catalina Francia ${ }^{1}$, Ana Isabel Azcurra ${ }^{2}$, \\ Mabel Brunotto ${ }^{2}$, Marcelo Ocampo ${ }^{3}$, José Atala ${ }^{3}$, Nicolás Bachur ${ }^{1}$, Alejandro Díaz ${ }^{1}$ \\ ${ }^{1}$ Universidad Nacional de Córdoba. Facultad de Odontología. Departamento de Patología Bucal, \\ ${ }^{2}$ Universidad Nacional de Córdoba. Facultad de Odontología. Departamento de Biología Bucal, \\ ${ }^{3}$ Universidad Nacional de Córdoba. Facultad de Odontología. Departamento de Rehabilitación Bucal,
}

\begin{abstract}
The objective of this study was to evaluate the effectiveness of the use of non-autogenous human bone using the maxillary sinus floor elevation technique to create favorable conditions for the placement of dental implants. Longitudinal clinical study of partially edentulous patients of both genders (included in this study $n=11$ ), older than 18 years. The data were recorded in three time periods: a) at the time of operation: b) control at 7 days, c) control at 180 days, these last two postoperative. The human bone grafts used were lyophilized and irradiated, with a particle size of 0.2 and $1 \mathrm{~mm}$, manufactured by the Hemoderivatives of the National University of Córdoba. The increase in bone tissue was measured by digital orthopantomography, as the distance obtained between the lower basal edge and the resulting alveolar ridge. The population was composed of 8 women and 3 men. The increase in bone reached, at 7 and 180 days, was observed radiographically. There was a significant increase in the mean values of bone $\mathrm{mm}$. Variations were $4-8 \mathrm{~mm}$ at the time of operation at mean values of $\geq 14 \mathrm{~mm}$ at 7 and 180 days after surgery. The results indicate that lyophilized human bone can be considered an alternative to bone grafts of animal origin or those of patients.
\end{abstract}

KEY WORDS: human bone graft; dental implant; sinus elevation

\section{Resumen}

El objetivo de este estudio fue evaluar la eficacia del uso de hueso humano no autógeno utilizando la técnica de elevación del piso del seno maxilar para crear condiciones favorables para la colocación de implantes dentales. Estudio clínico longitudinal de pacientes parcialmente edéntulos de ambos géneros (incluidos en este estudio $n=11$ ), mayores de 18 años. Los datos se registraron en tres momentos temporales: a) al momento de la operación: b) control a los 7 días, c) control a los 180 días, estos dos últimos pos operatorio. Los injertos de hueso humano empleados fueronliofilizados e irradiados, con un tamaño de partícula de 0.2 y $1 \mathrm{~mm}$, manufacturados por el Laboratorio de Hemoderivados de la Universidad Nacional de Córdoba. El aumento en el tejido óseo se midió mediante ortopantomografía digital, como la distancia obtenida entre el borde basal inferior y la cresta alveolar resultante. La población estaba compuesta por 8 mujeres y 3 hombres. El incremento de hueso alcanzado, a los 7 y 180 días, se observó radiográficamente. Se observó un aumento significativo en los valores medios de mm de hueso. Las variaciones fueron de 4-8 mm al momento de la operación a valores medios de $\geq 14 \mathrm{~mm}$ a los 7 y 180 días después de la cirugía.

Los resultados indican que el hueso humano liofilizado puede considerarse una alternativa a los injertos óseos de origen animal o a los propios del paciente.

PALABRAS CLAVE: injerto óseo humano; implante dental; elevación pido de seno 


\section{Introduction}

The adult population of the city of Córdoba currently has a high percentage of individuals with experience of dental extractions, single or multiple, which leads to a high incidence of esthetic and functional difficulties ${ }^{1}$. In the posterior sector of the upper jaws, bone remodeling following dental extractions coupled with the pneumatization of the maxillary sinus, leads to an unfavorable situation for rehabilitating the sector with osseointegrated implants that meet the basic biomechanical standards to support the corresponding prosthesis $^{2,3}$. One of the therapeutic strategies commonly used in surgical practice is the elevation of the maxillary sinus floor by placing autologous, allogeneic or other types of bone grafts, in order to create sufficient bone height in the sector to place osseointegrated implants that meet the basic biomechanical requirements to support stable and predictable prosthetic rehabilitation ${ }^{4,5}$.

Although, in general, the results are successful with these types of grafts, most researchers agree that the patient's own bone combines the best qualities since it is osteogenic, osteoinductive and osteoconductive $^{6}$. But it has the disadvantages of the post-surgical sequelae at the donor site, the need for longer and more bloody surgery, as well as the limited amount of bone that can be obtained, which is counter-productive for treatment ${ }^{7}$. One valid alternative is the use of Lyophilized Human Bone (LHB), which acts only as an osteoconductive material, favoring the formation of bone at the site where it is applied. When selecting the biomaterials, the effectiveness of each of the forms of presentation should be specially studied.

For this reason, the aim of this work was to evaluate the efficacy of the use of LHB in the partial reconstruction of maxillary atrophic residual alveolar ridges using the sinus floor lifting technique to obtain favorable conditions for the placement of dental implants.

\section{Material and methods}

A follow-up study was conducted of partially or totally edentulous patients, with mean residual bone height was $4-5 \mathrm{~mm}$, of both genders $(\mathrm{n}=15)$, over 18 years old, at the Clinical Office of Surgery
III (Dentistry School, National University of Cordoba, Argentina) between 2014 and 2015. The study consisted of three time-points: a) baseline; diagnosis and collection of data in clinical history; (b) control at 7 days, c) control at 180 days. The study was approved by the Research and Ethics Committee of the Ministry of Health of the Province of Cordoba (Facultad OdontologíaUniversidad Nacional Córdoba- n ODO67, ISRCTN11165901, DOI 10.1186/ISRCTN11165901) and informed consent forms were signed by all patients.

Patients with a history of type 1 diabetes mellitus, symptomatic hypo- or hyperthyroidism, immunodeficiency problems, sinusitis, chemotherapy and/or radiotherapy, arterial hypertension above 159/94, in the 6-month window period after acute myocardial infarction or cerebrovascular accident, with chronic periodontal disease, bone diseases such as osteomalacia, arthritis, infections, rheumatism or osteoporosis, cirrhosis, consumers of osteoactive drugs such as bisphosphonates, denosumab, raloxifene, teriparatide or corticoids or those who were pregnant, were excluded (Fig. 1).

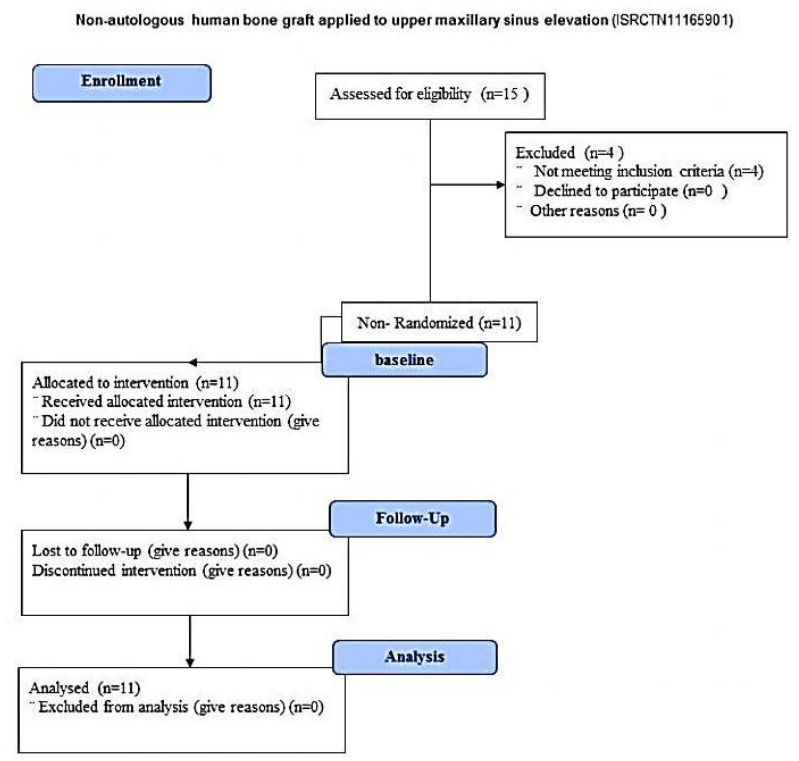

Figure 1. Consort flow diagram of study

\section{Surgery}

All the patients underwent the surgical technique of maxillary sinus floor elevation following the protocol of Tatum H Jr. $1986^{8}$ for surgeons of the 
team. To decrease the bacterial load, one minute's mouthwash with chlorhexidine was recommended every 12 hours for two days before the intervention and one prior to the intervention. An antibiotic prophylaxis regimen was established for all patients and consisted of the administration of amoxicillin/Clavulanic acid once 1 hour before surgery and for 7 days postoperatively ${ }^{9-12}$. To prevent inflammation and complications related to the intervention, the synthetic corticoids, dexamethasone or betamethasone (duo forms with phosphate and acetate salts) were used intramuscularly in a single dose, with a recommended start between 7 and 8 a.m. on the day of the intervention to avoid the suppression of the HPA (hypothalamic-pituitary-adrenal) axis. Local anesthesia was used with carticaine $4 \%$ and adrenaline 1:100,000. For the control of postoperative pain, ibuprofen or similar were recommended and in patients with intolerance to non-steroidal anti-inflammatory drugs, paracetamol every 6-8 h, depending on symptoms. This never exceeded $72 \mathrm{~h}$ Cryotherapy (local cold) was recommended, applied externally on the area affected as an alternative every 10 minutes during the first 24 hours, respecting the rest of the patient. All patients were instructed in post-surgical hygiene techniques to prevent local trauma.

The material used as a graft in the surgery was LHB and irradiated, composed of ground bone particles ranging from 0.2 to $1 \mathrm{~mm}$ in size from the Blood Bank of the National University of Córdoba (http://unc-

hemoderivados.com.ar/prodTejidos.php). Presentat ion: 0.5 and $1 \mathrm{~cm}^{3}$ blocks of cortical-spongy bone.

The increase in bone tissue was measured by digital orthopantomographs taken by a specialist using the standard technique for orthopantomography, model Planmeca Autoprint, PM 2002, with automatic processor Kodak XP 400, of the Diagnosis Imaging Department A and B of the School of Dentistry, Córdoba University. The tomography sections were taken every $2 \mathrm{~mm}$ in the zones intervened to measure the distance in millimeters obtained between the resulting floor of the maxillary sinus and the alveolar crest.

\section{Statistical analysis}

The data were described by their position (Mean/Median) and dispersion (range/standard error) parameters for quantitative variables, while the qualitative variables were described by their absolute or relative frequencies. The efficacy outcomes were evaluated by the Wilcoxon test for paired samples and associations between categorical variables by Fisher's Test. In all cases, a p-value of 0.05 was set for statistical significance.

\section{Results}

Of the 15 patients who started the study only 11 were eligible for meeting the study criteria (Fig. 1). The included population $(n=11)$ consisted of 8 women and 3 men. The mean age \pm standard deviation of the patients was $55.25 \pm 6.08$ years for women and $55.2 \pm 9.83$ for men. A total of 17 grafts was placed, as in some cases the technique was performed bilaterally, 13 of which $(76.4 \%)$ were placed in women and $4(23.5 \%)$ in men. In women, 7 of the grafts were located in the right sector and 6 in the left while, in males, 3 were in the right and 1 in the left. No significant association was observed between sector and gender (Fisher's test, $\mathrm{p}=0.4244$ ). All the patients in the study received dental implants and no periimplantitis or other sequel was recorded that would indicate a clinical failure of the restorative treatment.

Fig 2 shows, at radiographic level, the increase of bone achieved at 7 and 180 days. A variation was seen in mean values of $\mathrm{mm}$ of bone; it was initially 4-8 $\mathrm{mm}$, which significantly increased to average values of $14 \mathrm{~mm}$ and more, at 7 and 180 days after surgery (Fig 3 and Fig 4).

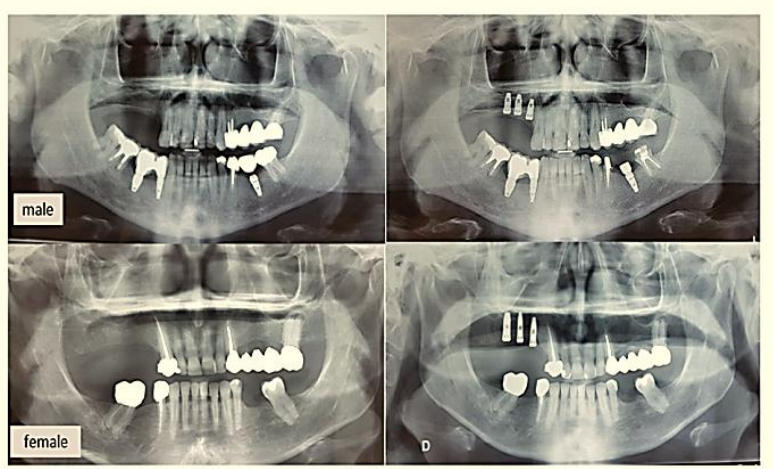

Figure 2. Orthopantomographic images of patients treated with maxillary sinus lifting surgery and with non-autogenous 
lyophilized human bone grafts, at baseline (left) and final at 180 days (right)

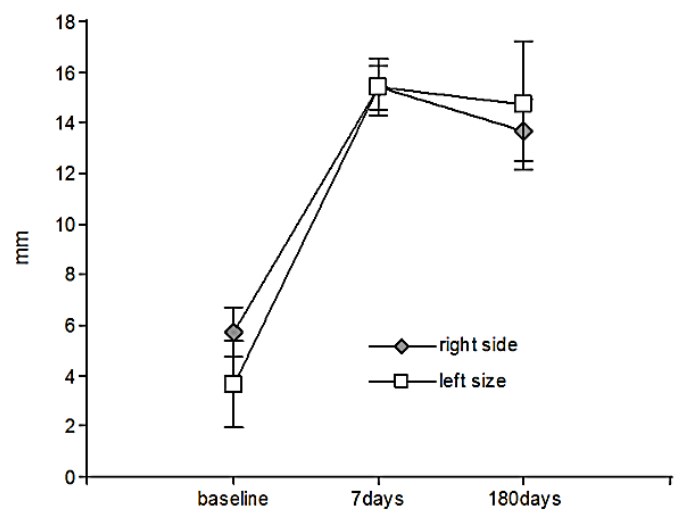

Figure 3. Measurement in millimeters ( $\mathrm{mm}$ ) of the increment in maxillary bone from human bone graft with the maxillary sinus floor elevation technique.Wilcoxon's (paired samples)

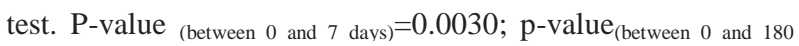
days $)=0.0324 ; \mathrm{p}$-value (between 7 and 180 days) $=0.7116$. Wilcoxon's (paired samples) test. P-value estimated by sampling of all possible permutations $(\mathrm{n}=5000)$. P-value $<0.05$ set for statistical significance

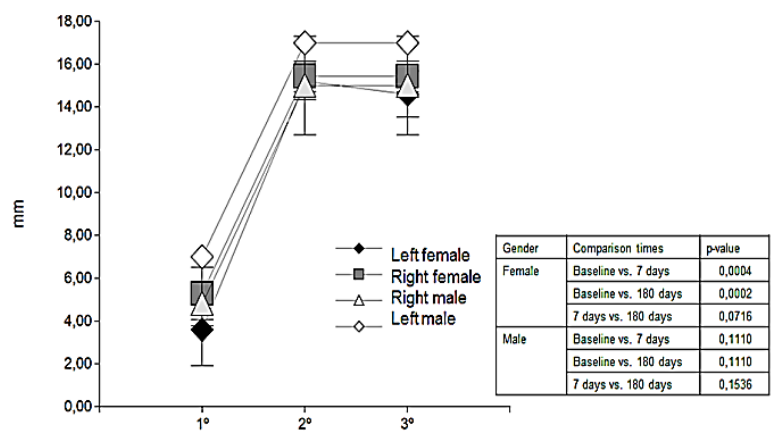

Figure 4.Measurement in millimeters $(\mathrm{mm})$ of the increment in maxillary bone from human bone graft with the maxillary sinus floor elevation technique, by gender. Wilcoxon's (paired samples) test. P-value estimated by sampling of all possible permutations $(\mathrm{n}=5000)$. $\mathrm{P}$-value $<0.05$ set for statistical significance - Axis $X: 1^{\text {st }}$ : baseline; $2^{\text {nd }}: 7$ days; $3^{\text {rd }}: 180$ days.

\section{Discussion}

The grafted bone in this study was not autogenous but was of human origin. In general, the gold standard of grafts is considered to be that performed with autogenous bone belong to patient, but xenogenic bone or synthetic materials are also used $^{13}$. Most studies indicate that the use of autogenous bone is better but that it also has negative consequences for the patient in the surgical sequelae in the bone extraction area ${ }^{14}$.Autogenous bone graft has been that most commonly used for the sinus floor elevation procedure for two decades. However, studies are now successfully using bone of non-human or synthetic origin in this type of surgical interventions ${ }^{15,16}$.

One of the most commonly used materials is BioOss (applied alone or with a proportion of autogenous bone). A systematic review has concluded that the volumetric stability of the graft after lifting the sinus floor increased significantly with the use of Bio-Oss alone or with a proportion of autogenous bone. The biological explanation of this has not yet been clearly established because of the scarce scientific animal studyliterature ${ }^{17}$. Research by Schmitt et al. 2015 showed no significant differences between the histology of the formation of de novo bone and residual bone in grafts from inorganic bovine bone or from autologous bone ${ }^{18}$.However, there is limited information on bone formation and the stability of autogenous bone grafts, because the graft is subject to bone remodeling of the site in which it is introduced $^{19}$. Experimental studies in animals have shown that there is a slight increase in the percentage of neo-formed autogenous bone at 6 months ${ }^{20}$. Another experiment in animal models comparing the result in bone formation of autogenous and bovine grafts, combined or alone with platelet-rich plasma, showed histologically a greater contact surface in grafts made with autogenous bone ${ }^{21}$.

Our study opted for sinus floor lift surgery because it is a procedure that has been carried out for 40 years with a high success rate. Tatum was the first to propose the placement of dental implants in sites with bone graft by raising the sinus floor with the lateral approach technique and its clinical application. This technique allowed the indication of the posterior maxillary region implant to be extended, with the advantage of a direct view when performing the surgery, the control of the height, effective protection of the sinus mucosa, the convenience of the bone graft and a precise positioning of the dental implant ${ }^{22,23}$. A drawback 
is the angle of the burr of each patient. Research results suggest that maxillary sinus floor lifting is a relatively simple, safe, and predictable technique for rehabilitation via implant in patients who have reduced vertical bone height in the posterior sector of the upper maxilla ${ }^{23}$. The objective proposed was to observe the results obtained with nonautogenous human bone.

In our research, a greater percentage of grafts (76.4\%) was placed in women than in men $(23.5 \%)$. The grafts were placed in the right sector of 7 women and 3 men, and in the left of 6 women and 1 man. $77 \%$ of bone grafts are performed in the anterior area of the maxilla for esthetic reasons. In a study conducted with a total of 1512 implants, they were placed in 421 males and 371 females $^{24}$.

Dental implants were successfully placed in all the patients included in this study with no periimplantitis or other sequela recorded that would indicate a clinical failure of the restorative treatment. Fig. 1 shows, radiographically, the increase of bone achieved at 7 and 180 days. We observed a variation of $4-8 \mathrm{~mm}$ in average values of $\mathrm{mm}$ of bone at the beginning, significantly increasing to average values of $14 \mathrm{~mm}$ and more at 7 and 180 days after surgery (average percentage of increment $66 \%$ ). In agreement with our study, Netto et al.2016,using autogenous bone grafts, observed an average increase in bone formation of $38.45 \pm 6.64 \%$ (less than that observed in our study) without significant variations between the times studied ${ }^{25}$.

In conclusion, the use of bone grafts of nonautogenous human origin for the first time in this study showed a highly significant increase in bone formation in a short time and allowed the successful placement of dental implants. This new type of graft broadens the spectrum of restorative dental treatments that can be considered in this type of dental surgery, probably presenting characteristics similar to those of autogenous bone, which until now remains the gold standard.

\section{Acknowledgments}

The authors received financial support from the Secretaria de Ciencia y Técnica of the Universidad Nacional de Córdoba (Res SECYT UNC 075/14).
Todos los autores declaran que no existen conflictos potenciales de interés con respecto a la autoría y / o publicación de este artículo.

All authors declare no potential conflicts of interest with respect to the authorship and/or publication of this article

\section{References}

1. Mangano C, Scarano A, Perrotti V., Iezzi G, Piattelli A. Maxillary sinus augmentation with a porous synthetic hydroxyapatite and bovine derived hydroxyapatite: comparative clinical and histological study. International Journal of Oral and Maxillofacial Implants 2007; 22: 980-986.

2. Murthy A.S. Lehman J.A. Secondary alveolar bone grafting:An outcome analysis. Can J Plast Surg. 2006;14: 172-4.

3. Ballini A, Cantore S, Capodiferro S, GrassiFR. Esterified Hyaluronic Acid and Autologous Bone in the Surgical Correction of the Infra-Bone Defects. Int $\mathrm{J}$ Med Sci. 2009; 6: 65-71.

4. Brand RA. Repair of bone in the presence of aseptic necrosis resulting from fractures, transplantations and vascular obstruction. ClinOrthopRelat Res. 2008; 466:1020-1.

5. Huh JB, Park CK, Kim SE, Shim KM, Choi KH, Kim SJ, Shim JS, Shin SW. Alveolar ridge augmentation using anodized implant coated with Escherichia coliderived recombinant human bone morphogenetic protein 2. Oral Surg. Oral Med. Oral Pathol Oral RadiolEndod. 2011; 112:42-9.doi: 10.1016/j.tripleo.2010.09.063.

6. Funaki K, Takahashi T, Yamuchi K.Horizontal alveolar ridge augmentation using distraction osteogenesis: comparison with a bone-splitting method in a dog model. Oral Surg. Oral Med. Oral Pathol Oral RadilEndod. 2009; 107:350-358.doi: 10.1016/j.tripleo.2008.10.005.

7. Gruber R, Stadlinger B, Terheyden H. Cell-to-cell communication in guided bone regeneration: molecular and cellular mechanisms. Clin Oral Implants Res. 2016. doi: 10.1111/clr.12929.

8. Pollock R, Alcelik I, Bhatia A, Chuter CG, Kiran L, Budithi $\mathrm{C}$ and Krishna, M. Donor site morbidity following iliac crest bone harvesting for cervical fusion: a comparison between minimally invasive and open techniques. Eur Spine J. 200;17: 845-52.

9. Tatum H Jr. Maxillary and sinus implant reconstructions. Dent Clin N Am 1986; 30:207-229.

10. Bowen-Antolín A, Pascua-García MT, Nasimi A. Infections in implantology: From prophylaxis to treatment. Med Oral Patol Oral Cir Bucal.2007; 12(4):E323-30. 
11. Gutiérrez JL, Bagán JV, Bascones A, LlamasR, Llena J, Morales A, Noguero 1B, Planells P, Prieto J, Salmerón JI. Consensus document on the use of antibiotic prophylaxis in dental surgery and procedures. Med Oral Patol Oral Cir Bucal. 2006; 11:E188-E205.

12. Poveda-Roda R, Bagán JV, Sanchis-Bielsa JM, Carbonell-Pastor E. Antibiotic use indental practice.Areview. Med Oral Patol Oral Cir Bucal 2007; 12:E186-92.

13. Moreno Vázquez JC, González de Rivera AS, Serrano Gil H, Santamaria Mifsut R. Complication Rate in 200 Consecutive Sinus Lift Procedures: Guidelines for PreventionandTreatment.J Oral MaxillofacSurg.2014; 72:892-901.

14. Cassetta M, Perrotti V, Calasso S, Piattelli A, Sinjari $\mathrm{B}$, Iezzi G. Bone formation in sinus augmentation procedures using autologous bone, porcine bone, and a 50: 50 mixture: a human clinical and histological evaluation at 2 months. Clin Oral Implants Res. 2015; 26(10):1180-4

15. Pistilli R, Felice P, Piatelli M, Nisii A, Barausse C, Esposito M.Blocks of autogenous bone versus xenografts for the rehabilitation of atrophic jaws with dental implants: preliminary data from a pilot randomised controlled trial. Eur J Oral Implantol. 2014;7(2):153-71.

16. Gorla LF, Spin-Neto R, Boos FB, Pereira Rdos S, GarciaJunior IR, Hochuli-Vieira E. Use of autogenous bone and beta-tricalcium phosphate in maxillary sinus lifting: a prospective, randomized, volumetric computed tomography study. Int $\mathrm{J}$ Oral Maxillofac Surg. 2015;44(12):1486-91.

17. Rickert D, Slater JJ, Meijer HJ, Vissink A, Raghoebar GM. Maxillary sinus lift with solely autogenous bone compared to a combination of autogenous bone and growth factors or (solely) bone substitutes. A systematic review. Int J Oral Maxillofac Surg. 2012;41(2):160-7.

18. Jensen T, Schou S, Stavropoulos A, Terheyden H, Holmstrup P. Maxillary sinus floor augmentation with Bio-Oss or Bio-Oss mixed with autogenous bone as graft in animals: a systematic review. Int $\mathbf{J}$ Oral Maxillofac Surg. 2012; 41(1):114-20

19. Schmitt CM, Moest T, Lutz R, Neukam FW, Schlegel KA. Anorganic bovine bone (ABB) vs. autologous bone $(\mathrm{AB})$ plus $\mathrm{ABB}$ in maxillary sinus grafting. A prospective non-randomized clinical and histomorphometrical trial. Clin Oral Implants Res. 2015; 26(9):1043-50

20. Thomas MV, Puleo DA. Infection, inflammation, and bone regeneration: a paradoxical relationship. J Dent Res. 2011; 90(9):1052-61.

21. Lee HJ, Choi BH, Jung JH, Zhu SJ, Lee SH, Huh JY, You TM, Li J. Maxillary sinus floor augmentation using autogenous bone grafts and platelet-enriched fibrin glue with simultaneous implant placement. Oral Surg Oral
Med Oral Pathol Oral Radiol Endod. 2007; 103(3):32933.

22. Schlegel KA, Zimmermann R, Thorwarth M, Neukam FW, Klongnoi B, Nkenke E, Felszeghy E. Sinus floor elevation using autogenous bone or bone substitute combined with platelet-rich plasma. Oral Surg Oral Med Oral Pathol Oral Radiol Endod. 2007; 104(3):e15-25.

23. Raja SV. Management of the posterior maxilla with sinus lift: Review of techniques. J Oral Maxillofac Surg. 2009; 67(8):1730-4.

24. Peng W, Kim IK, Cho HY, Pae SP, Jung BS, Cho HW, Seo JH. Assessment of the autogenous bone graft for sinus elevation. J Korean Assoc Oral Maxillofac Surg. 2013; 39(6):274-82.

25. Cha HS, Kim JW, Hwang JH, Ahn KM. Frequency of bone graft in implant surgery. Maxillofac Plast Reconstr Surg. 2016 Mar 31; 38(1):19.

26. Netto HD, Miranda Chaves MD, Aatrstrup B, Guerra R, Olate S. Bone Formation in Maxillary Sinus Lift Using Autogenous Bone Graft at 2 and 6 Months. Int J Morphol. 2016; 34(3):1069-1075.

Corresponding to/Correspondencia a: Dr. Ricardo Bachur Universidad Nacional de Córdoba, Facultad de Odontología Departamento de Patología Bucal Haya de La Torre s/n Ciudad Universitaria, CP 5000, Córdoba, Argentina. Tel.: +543514333032.

E-mail/Correo electrónico: ricardo.bachur@unc.edu.ar 